\title{
45. NONVOLATILE ORGANIC MATTER IN SEDIMENTS FROM SITES 614 TO 623, DEEP SEA DRILLING PROJECT LEG 96 1
}

\author{
M. C. Kennicutt II, D. A. DeFreitas, J. E. Joyce, and J. M. Brooks, Texas A\&M University ${ }^{2}$
}

\begin{abstract}
The bulk organic matter in sediments from the upper Pleistocene Mississippi Fan and two intraslope basins is primarily terrestrial in origin. Carbon to nitrogen elemental ratios, $\delta^{13} \mathrm{C}$ of the organic matter, the presence of plant biowaxes, and lithologic associations form the basis of this interpretation. The molecular-level compositions of the extractable organic matter suggest significant levels of non-indigenous thermogenic hydrocarbons at all sites. The alkane hydrocarbons are composed of both biogenic (mainly plant biowaxes) and thermogenic hydrocarbons. The thermogenic hydrocarbons are primarily present as an unresolved complex mixture. Increasing amounts of hydrocarbons with depth at the Mississippi Fan sites suggest that the thermogenic hydrocarbons have migrated upward from deeper sediments. Vertical gradients in the intraslope basins were less dramatic, although an upward migration source is inferred. Upward movement of thermogenic hydrocarbons, from deeper sediments where sufficient temperatures are present to produce these hydrocarbons, appears to be a regional phenomenon given the widespread occurrence at these sites.
\end{abstract}

\section{INTRODUCTION}

In a continuing effort to document and more fully understand the chemistry and early diagenesis of organic matter in Recent marine sediments, clayey samples were obtained in the Gulf of Mexico during DSDP Leg 96 aboard the Glomar Challenger. Both Mississippi Fan and intraslope basin sites were sampled (Fig. 1). The distribution of terrestrial and marine organic matter in sediments can be used to define paleoceanographic conditions, as well as to predict the distribution of oil- and gas-producing zones in passive margins (Barker, 1979). Because of the different economic potential of oil and gas deposits, it is important to understand the factors controlling the distribution of organic matter types.

Attempts to differentiate marine and terrestrial organic matter have historically been based on chemical ( $n$-alkanes, lignin, elemental composition) and isotopic $\left(\delta^{13} \mathrm{C}\right)$ characteristics (Eckleman et al., 1962; Sackett and Thompson, 1963; Sackett, 1964; Gardner and Menzel, 1974; Hedges and Parker, 1976; Gearing et al., 1977, 1984; Prahl and Carpenter, 1979; Prahl et al., 1980; Meyers et al., 1984). $\delta^{13} \mathrm{C}$ values of marine planktonic debris range from about -19 to $-23 \%$ (vs. Pee Dee belemnite); land plants fall within a $\delta^{13} \mathrm{C}$ range of -23 to $-32 \%$, with an average value of $-25 \%$ (Gearing et al., 1984). Differentiation of organic matter sources on the basis of carbon-isotope composition is complicated by: (1) the overlap of the isotopic composition of marine and terrestrial plants $\left(\mathrm{C}_{3}\right.$ and $\mathrm{C}_{4}$ plants); (2) the effects of water temperature on the fractionation of carbon in plankton; (3) the alteration of organic matter isotopic composition during degradation and diagenesis; (4) upward and/or lateral migration of petrogenic hydrocar-

\footnotetext{
${ }^{1}$ Bouma, A. H., Coleman, J. M., Meyer, A. W., et al., Init. Repts. DSDP, 96: Washington (U.S. Govt. Printing Office). 77843 .
}

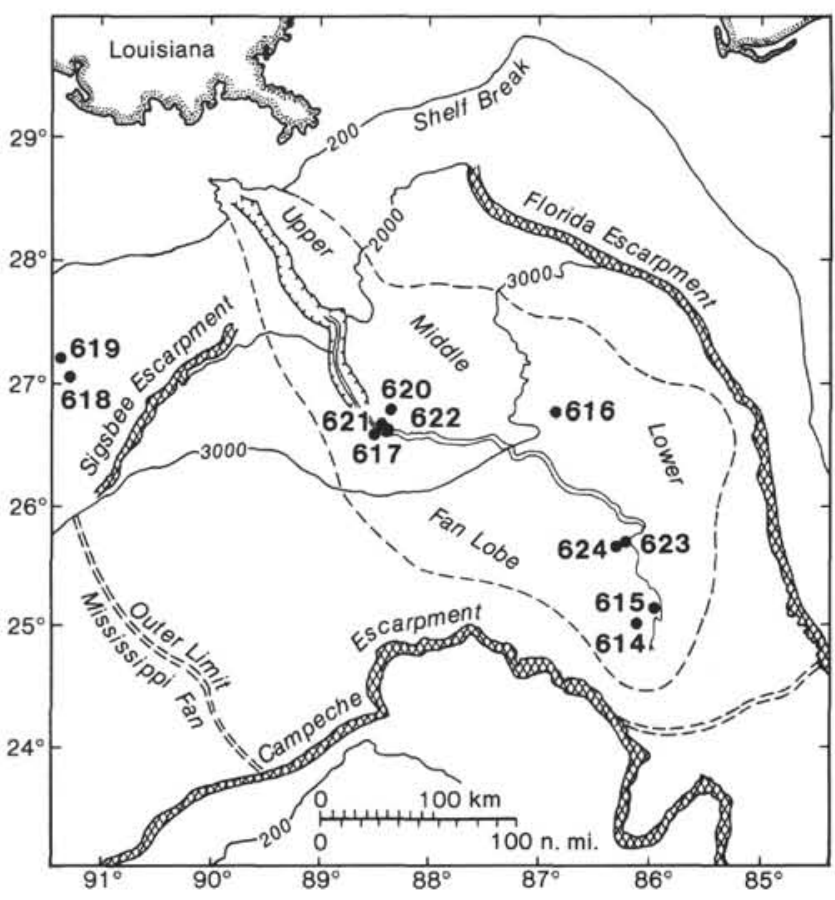

Figure 1. Site locations for DSDP Leg 96.

bons into shallower sediments $\left(\delta^{13} \mathrm{C}=\sim-24\right.$ to $-31 \% 0$ ); (5) anomalous isotopic compositions produced in localized (closed) environments; and (6) the incorporation of recycled organic matter into younger sediments (Gearing et al., 1977, 1984). Despite these limitations, carbon-isotope compositions are useful in understanding the distribution of organic matter in recent sedimentary environments.

The presence of long chain alkanes $\left(>n-\mathrm{C}_{22}\right)$ with a strong odd over even carbon preference is also a useful indicator of terrestrial input (Eglinton and Hamilton, 1963; Kollatukudy and Walton, 1973; Gearing et al., 1976; Tullock, 1976; Giger and Schaffner, 1977; Farrington and 
Tripp, 1977; Giger et al., 1980). Surface cuticle waxes, which prevent evaporation in higher plants, are esters of long chain acids and alcohols and produce long chain normal alkanes when degraded (Eglinton and Hamilton, 1963, 1967). These higher plants appear to be the only biological source of normal alkanes with chain lengths greater than $n-\mathrm{C}_{25}$ in recent sediments. Organic carbonto-nitrogen elemental ratios are also useful in differentiating sources because marine organisms are enriched in nitrogen compared to terrestrial plants (Müller, 1977; Prahl et al., 1980; Meyers et al., 1984). Marine organisms have $\mathrm{C} / \mathrm{N}$ ratios ranging from 6 to 8 whereas land plants generally have ratios greater than 12 .

Hydrocarbons generated from thermogenic processes can be distinguished at the molecular level from in situ biogenic hydrocarbons. The parameters used to differentiate thermogenic and biogenic hydrocarbons have been extensively discussed elsewhere and will only be briefly described here (Farrington et al., 1973; Wakeham and Carpenter, 1976; Farrington and Tripp, 1977; Meyers et al., 1984). Thermogenic hydrocarbons consist of a complex mixture of alkanes, cycloalkanes, branched alkanes, aromatic compounds, polar compounds, and large macromolecular structures. In contrast, hydrocarbons derived from biological sources are simple mixtures comprising only a few hydrocarbons including alkanes ( $n$ $\mathrm{C}_{15}, n-\mathrm{C}_{17}$, pristane) and alkenes (Giger et al., 1980). As previously mentioned, plant biowaxes also occur in recent sediments with odd number carbon lengths from 23 to 33 (or greater). Unaltered thermogenic hydrocarbons generally contain a complete suite of normal alkanes with little or no carbon preference, which can be represented by a carbon preference index (CPI), that is, the ratio of the concentration of odd alkanes to even alkanes over a given carbon range (Wakeham and Carpenter, 1976; Farrington and Tripp, 1977). Thermogenic hydrocarbons also contain a gas chromatographically unresolved complex mixture (UCM) (Farrington et al., 1973; Farrington and Tripp, 1977). Only minor amounts of aromatic hydrocarbons are produced by organisms. Twoto five-ring aromatic compounds are assumed to be thermogenic in origin.

The presence of thermogenic hydrocarbons in shallow buried sediments, where neither sufficient temperature nor time has been available to produce hydrocarbons, implies either (1) upward migration from deeper sources, (2) anthropogenic inputs (pollution), (3) the incorporation of recycled thermally mature material, and/ or (4) low temperature abiotic production. Differentiation between upward migration and pollution sources can be made by vertical distributions. The effect of recycled material is difficult to determine and must be examined in relationship to other stratigraphic data. Low temperature abiotic production of hydrocarbons is thought to be minimal.

The continental shelf and slope region of the Gulf of Mexico is known to be a site of extensive oil and gas seepage (Anderson et al., 1983; Brooks et al., 1984). DSDP Leg 96 presented an opportunity to examine the possible upward migration of hydrocarbons in the Mississippi Fan and in two intraslope basins of the Gulf of Mexico (Fig.
1). The sites also allowed the comparison of sediments underlying oxygenated waters (Pigmy Basin, Site 619) versus those underlying an anoxic, hypersaline brine (Orca Basin, Site 618).

Bulk- as well as molecular-level parameters were determine vertically at each site. Parameters measured include percentage organic carbon, $\mathrm{C} / \mathrm{N}$ elemental ratios, $\delta^{13} \mathrm{C}$-organic matter, extractable organic matter concentration (EOM), as well as individual alkane and unresolved complex mixture (UCM) concentrations. Interstitial waters were analyzed for sulfate and total $\mathrm{CO}_{2}$ content to assess the level of microbial activity and the onset of methanogenesis.

\section{METHODS}

All analytical methods used in this study are described in detail elsewhere (Kennicutt et al., 1985; Kennicutt and Jeffrey, 1981a,b). Organic carbon and nitrogen concentrations were determined by combustion with a Perkin Elmer Model $240 \mathrm{C}$ Elemental Analyzer. $\delta^{13} \mathrm{C}$ was determined on the bulk organic matter by a method similar to that of Sackett et al. (1970). $\delta^{13} \mathrm{C}$ values are reported as part per thousand $(\%)$ deviation from the limestone Pee Dee belemnite (PDB) standard.

Freeze-dried sediments were Soxhlet extracted for $12 \mathrm{hr}$. with hexane. The extracts were analyzed using total scanning fluorescence (Brooks et al., 1983; Kennicutt and Brooks, 1983) and fused silica capillary gas chromatography. Total extractable organic matter was determined gravimetrically on a Cahn Electrobalance (Model 29). The concentration of individual alkanes was calculated from authentic standards and corrected for internal standard recoveries. The carbon preference index (CPI) is defined as the ratio of the concentration of the odd numbered normal alkanes with 23 to 31 carbons to the even numbered normal alkanes with 24 to 32 carbons. The unresolved complex mixture (UCM) was semiquantitatively determined by calculating concentrations using the flame ionization detector response for a normal alkane eluting in the same gas chromatographic region as the UCM. Interstitial sulfate levels were measured turbidimetrically with a Technicon Autoanalyzer II and total $\mathrm{CO}_{2}$ by acidification and infrared detection.

\section{RESULTS}

\section{Lower Fan Sites (614, 615, and 623)}

Lower fan Sites 614 and 615 are located near the ends of the lower fan channels and their interfingering lobes (Fig. 1; see site chapters, this volume). At Site 614, the recovered sediments consist primarily of clay and sand ( $70 \%$ net sand) overlain by $\sim 1.5 \mathrm{~m}$ of Holocene marly foraminiferal ooze. The upper Pleistocene section is primarily turbidites. At Site $615,523.2 \mathrm{~m}$ of section was penetrated, including two fan lobes and the top of a third lobe. The top $0.5 \mathrm{~m}$ of the section is Holocene in age. The rest of the section is predominantly the result of turbidity flows ( $\sim 40-60 \%$ sand). Site 623 is located in a transitional zone between the middle and lower fan areas on the edge of a buried channel. Approximately $25 \mathrm{~cm}$ of Holocene section was recovered at this site. In general, the section below the Holocene section represents interbedded channel fill and overbank deposits and forms an indistinct upward fining sequence. Site 624 was very similar to Site 623 and was not analyzed in detail.

Interstitial sulfate $\left(\mathrm{SO}_{4}{ }^{2-}\right)$ and total $\mathrm{CO}_{2}\left(\mathrm{\Sigma CO}_{2}\right)$ concentrations range from 0.0 to $32.6 \mathrm{mM}$ and 28.1 to 99.3 $\mathrm{mg} \mathrm{C} / \mathrm{L}$, respectively (Figs. 2 and 3 ). Sulfate concentrations below the detection limit $(0.2 \mathrm{mM})$ were observed only at Site 615. In general, little or no sulfate reduction 


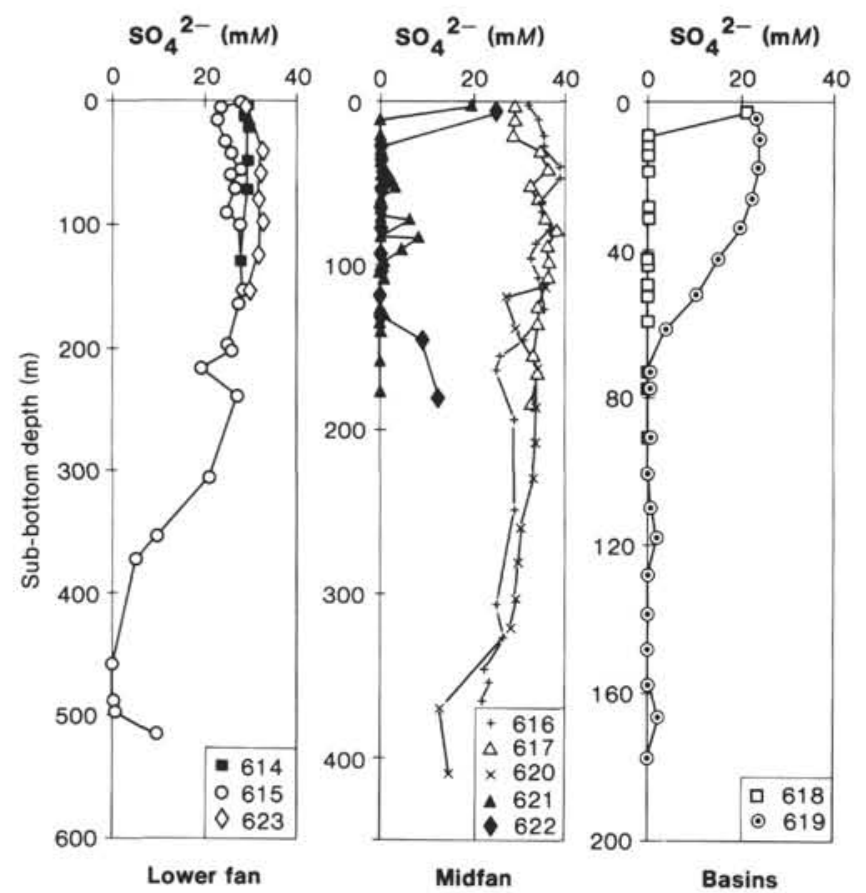

Figure 2. Vertical distribution of interstitial sulfate $\left(\mathrm{SO}_{4}{ }^{2-}\right)$ concentrations at DSDP Leg 96 sites.

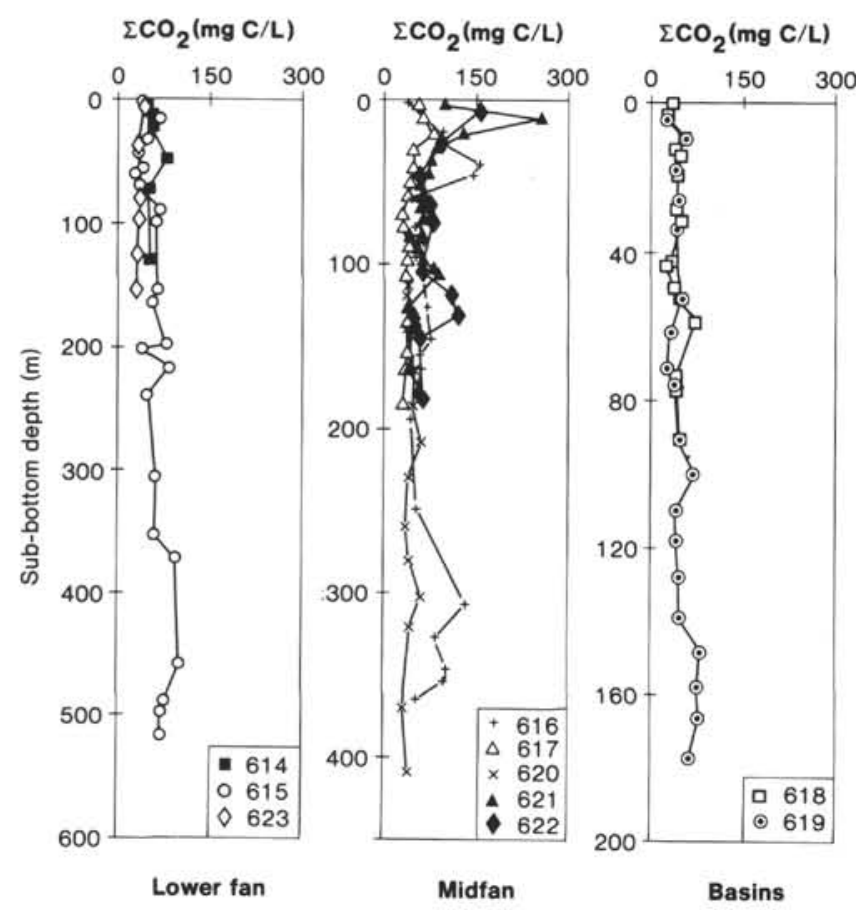

Figure 3. Vertical distribution of interstitial total carbon dioxide $\left(\mathrm{\Sigma CO}_{2}\right)$ concentrations at DSDP Leg 96 sites.

was observed in cores from the lower fan sites. Sulfate reduction is manifested as a decrease in sulfate concentration to values less than that of seawater $(\sim 28 \mathrm{mM})$. $\Sigma \mathrm{CO}_{2}$ concentrations exhibit no trend with depth and are relatively constant.

Organic carbon content (TOC) varies from 0.1 to $1.7 \%$ and averages $1.0 \pm 0.4 \%(n=38)$ at the lower fan sites
(Fig. 4). Carbon to nitrogen elemental ratios $(\mathrm{C} / \mathrm{N})$ vary from 11.1 to $>90$ and are indicative of a predominantly terrestrially sourced organic matter. A terrestrial source for the organic matter is also suggested by the $\delta^{13} \mathrm{C}$ values which range from -25.2 to $-27.7 \%$. The -25 to $-27 \% 0{ }^{13} \mathrm{C}$ values in the Ericson $\mathrm{Z}$ zone (Ericson and Wollin, 1968), the Holocene section, are contrary to published data and are probably a result of displaced Pleistocene material (Newman et al., 1973). Carbon-isotope compositions are relatively monotonous with depth (Fig. 4).

Extractable organic matter varies from 8.8 to 222.2 ppm (dry weight of sediment) and shows no trend with depth. Individual $n$-alkane distributions are indicative of a mixed terrestrial and petrogenic source. A complete suite of $n$-alkanes from $n-\mathrm{C}_{15}$ to $n-\mathrm{C}_{34}$ is present as well as the isoprenoids pristane and phytane (Fig. 5A). The resolved alkanes are accompanied by a significant UCM indicative of petroleum hydrocarbons. Individual $n$-alkane concentrations range from 0 to $>1000 \mathrm{ppb}$ but are generally in the $10-500 \mathrm{ppb}$ range. $n-\mathrm{C}_{17}, n-\mathrm{C}_{20}$, pristane, and phytane concentrations range from 7.5 to 349 , 14.9 to $239,12.6$ to 475 , and 9.0 to $272 \mathrm{ppb}$, respectively (Figs. 6 and 7). The total UCM ranges from 1.4 to 53.9 ppm (Fig. 7). Total resolved alkanes generally account for less than $10 \%$ of the total hydrocarbons (total hydrocarbon $=\mathrm{UCM}+$ total resolved hydrocarbons). Vertical distributions of $n$-alkanes, isoprenoids, the UCM, and the CPI suggest that the source of the thermogenic hydrocarbons is more deeply buried sediments. Individual alkane concentrations increase by as much as sevenfold over the length of the cores (Fig. 6). The UCM increases by a factor of more than three with depth, while the CPI decreases by more than $50 \%$ (Figs. 6 and 7).
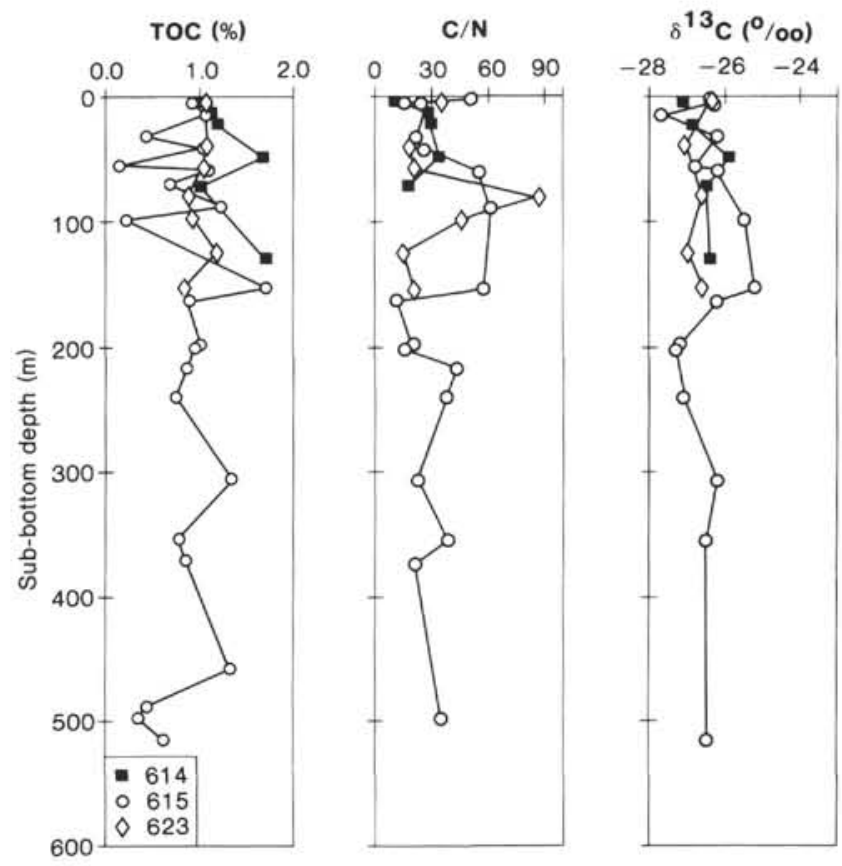

Figure 4. Vertical distribution of total organic carbon content (TOC), organic carbon to nitrogen elemental ratios $(\mathrm{C} / \mathrm{N})$, and $\delta^{13} \mathrm{C}$ of organic matter at the lower fan sites. 

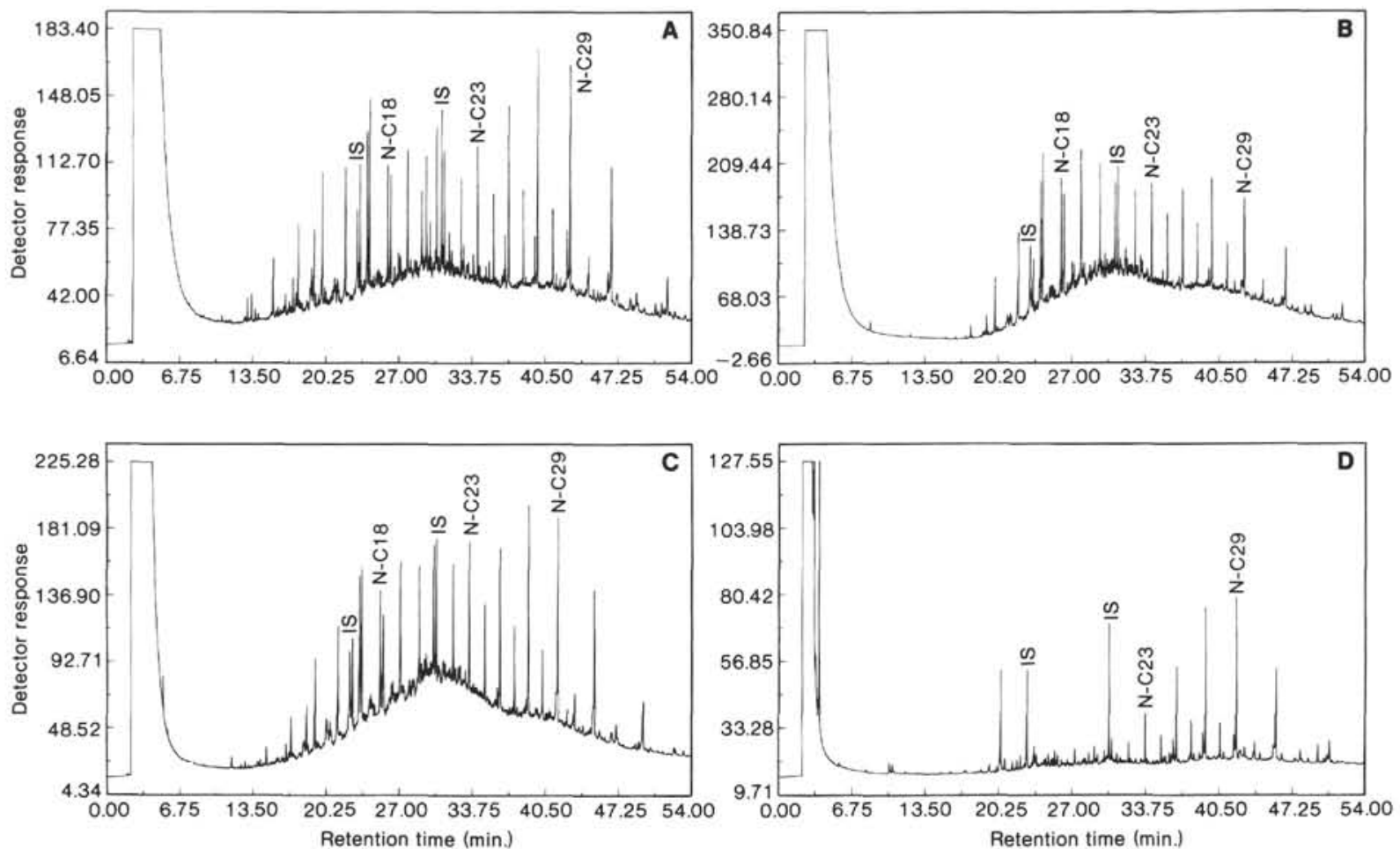

Figure 5. Gas chromatograms of sediment extracts from Mississippi Fan sites. (A) Site 615, lower fan, $306.15 \mathrm{~m}$ sub-bottom; (B) Site 617, middle fan levee, $163.94 \mathrm{~m}$ sub-bottom; (C) Site 620, middle fan overbank, $369.92 \mathrm{~m}$ sub-bottom; (D) Site 621, middle fan channel, $36.64 \mathrm{~m}$ sub-bottom. Chromatographic conditions: $40^{\circ} \mathrm{C}(1 \mathrm{~min}.) \rightarrow 80^{\circ} \mathrm{C}$ at $30^{\circ} \mathrm{C} / \mathrm{min} ., 80^{\circ} \mathrm{C}(0 \mathrm{~min}$. $) \rightarrow 300^{\circ} \mathrm{C}$ at $6^{\circ} \mathrm{C} / \mathrm{min}$., $300^{\circ} \mathrm{C}$ for $15 \mathrm{~min}$.; 50 -m fused silica column $(0.25-\mathrm{mm} \mathrm{ID})$ coated with $50 \mathrm{BP} 1 / \mathrm{QC} 2$ (SGE Ltd.); inj. port $-300^{\circ} \mathrm{C}$, FID $-350^{\circ} \mathrm{C}$; helium carrier gas flow $2-3 \mathrm{ml} / \mathrm{min}$.

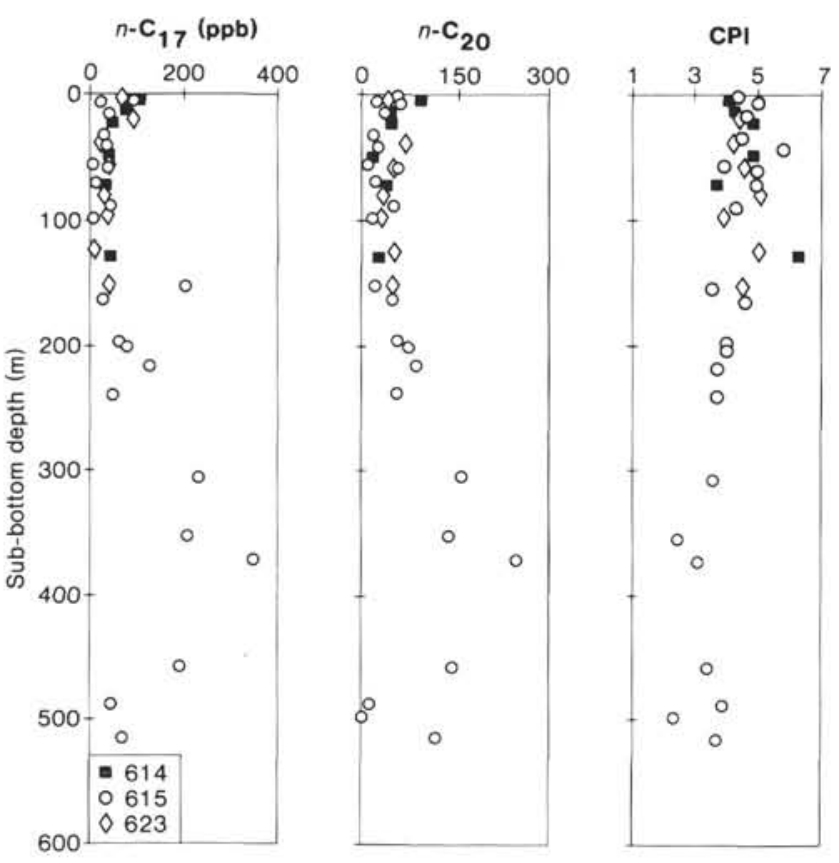

Figure 6. Vertical distribution of $n-\mathrm{C}_{17}, n-\mathrm{C}_{20}$, and carbon preference index (CPI) at lower fan sites.

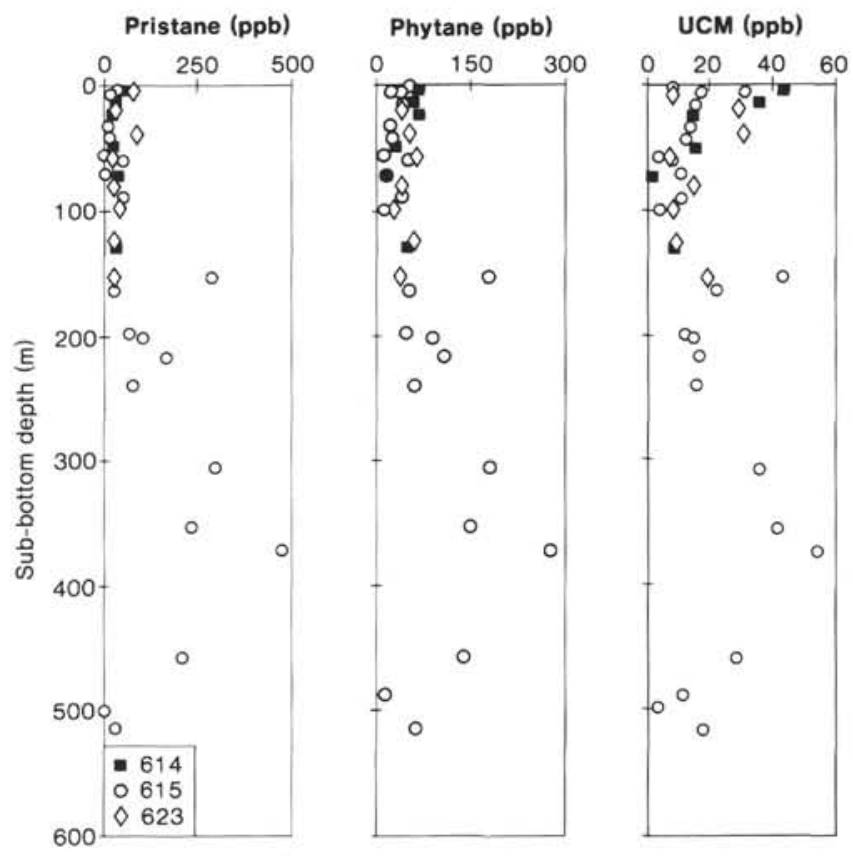

Figure 7. Vertical distribution of pristane, phytane, and the unresolved complex mixture (UCM) at lower fan sites. 
Total scanning fluorescence analysis of Soxhlet extracts suggest the presence of significant amounts of 2to 5-ring aromatic compounds at all lower fan site locations. Examples of characteristic total scanning fluorescence spectra of extracts of sediment from the lower fan sites are presented in Figure 8. As can be seen by comparison with the middle fan data shown in Figure 9, these spectral characteristics are representative of all fan sites. Two spectral maxima are usually present, one at

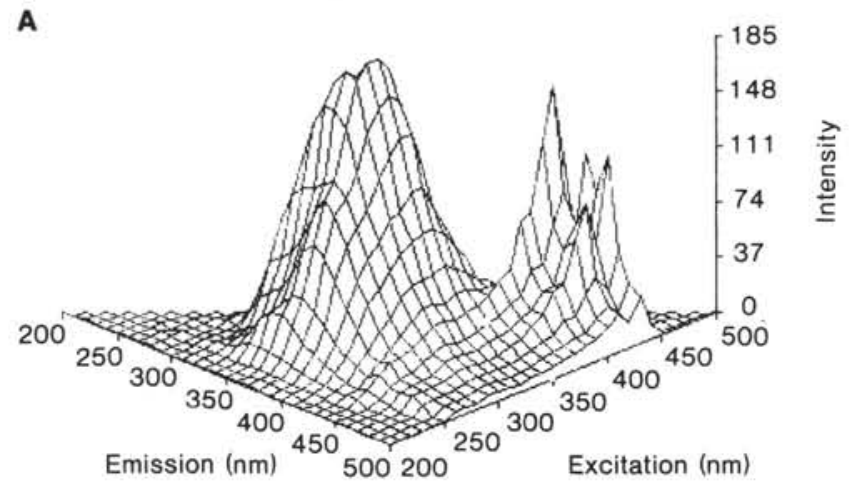

B
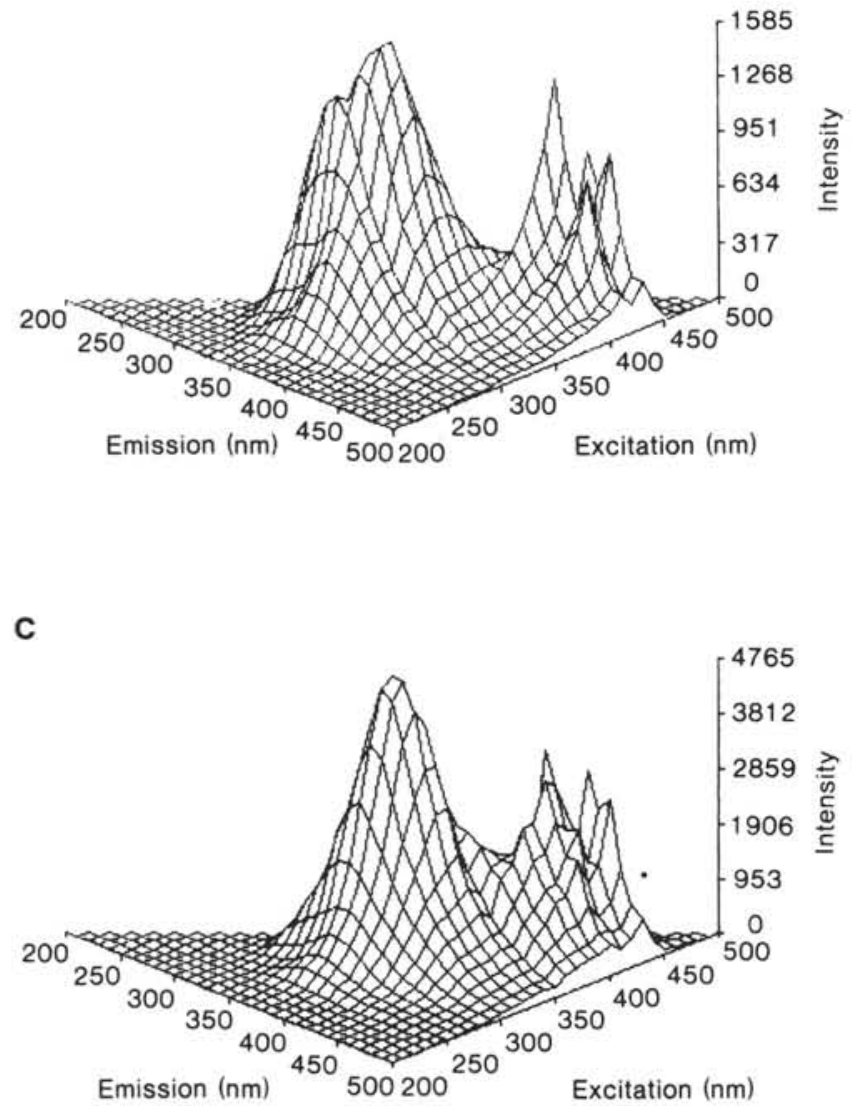

Figure 8. Selected total scanning fluorescence spectra of extracts of sediments from lower fan Site 615. (A) $32.55 \mathrm{~m}$ sub-bottom, (B) $306.15 \mathrm{~m}$ sub-bottom, (C) $372.57 \mathrm{~m}$ sub-bottom.
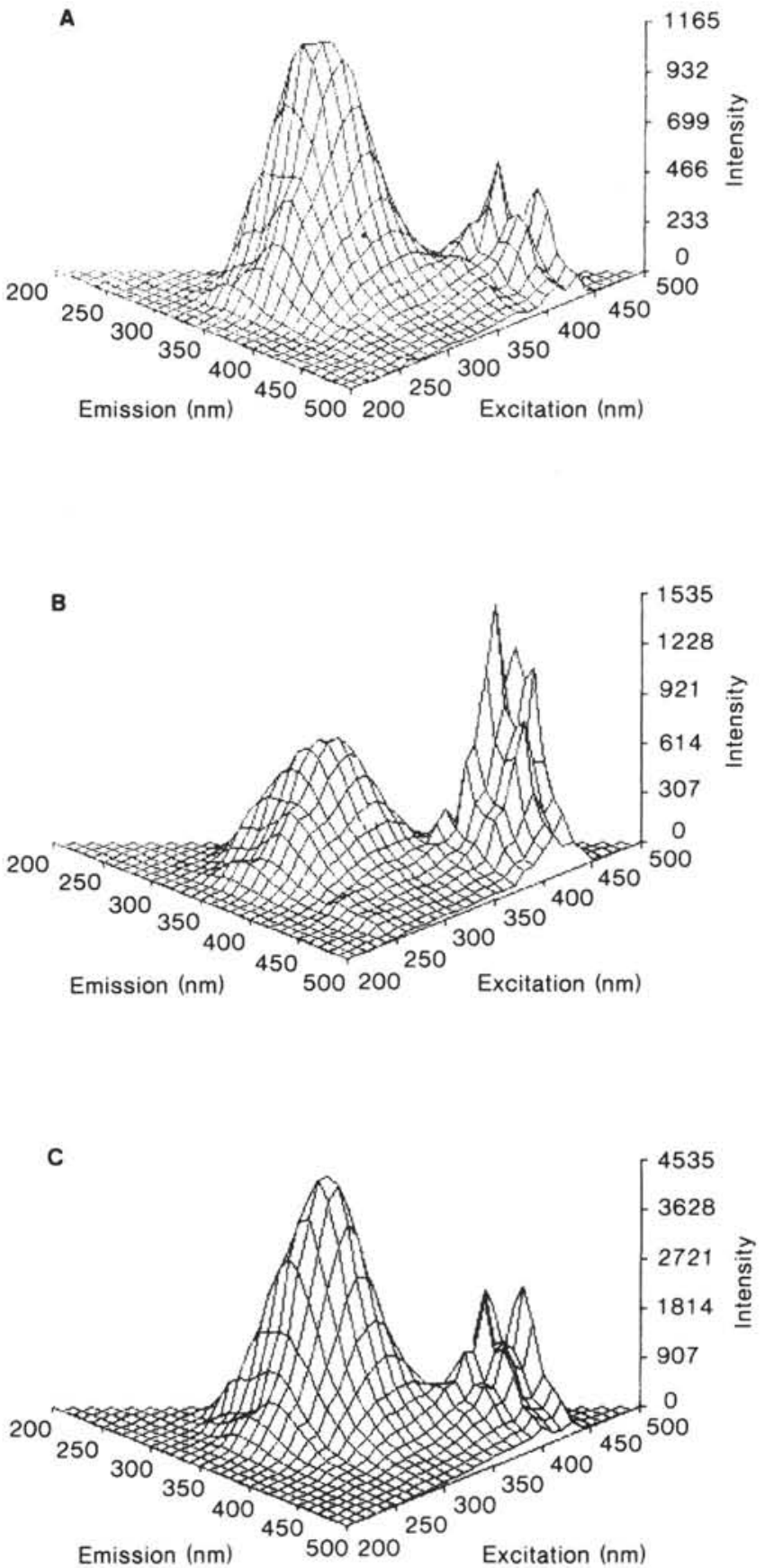

Figure 9. Selected total scanning fluorescence spectra of extracts of sediments from fan margin and middle fan sites. (A) Site 616, $249.14 \mathrm{~m}$ sub-bottom depth, (B) Site $617,77.84 \mathrm{~m}$ sub-bottom depth, (C) Site 620, $280.72 \mathrm{~m}$ sub-bottom depth.

lower wavelengths ( $<350 \mathrm{~nm}$ excitation) from petroleum-related aromatic compounds and one at higher wavelengths (>400 $\mathrm{nm}$ excitation) from indigenous aromatic compounds (perylenes). These spectral interpretations are confirmed by individual aromatic compound analysis by high performance liquid chromatography (HPLC) with photodiode array ultraviolet spectrophotometric detection and gas chromatography/mass spectrometry analyses that will be reported in a later publication. 
Middle Fan Sites (617, 620, 621, and 622)

Sites selected for the midfan drilling locations provided samples from three morphological settings: Sites 621 and 622 in the central channel, Site 617 in a swale near the inner bend of the local channel meander, and Site 620 in an overbank deposit (Fig. 1; see site chapters, this volume). At Site 617, we cored to a depth of $191.2 \mathrm{~m}$ and recovered primarily levee-overbank deposits. The Holocene section is $25 \mathrm{~cm}$ thick and consists of a marly foraminiferal ooze. The remainder of the core contains thin-bedded mud turbidites and muds with silt laminae and thin silt beds. Site 620 penetrated to $422.7 \mathrm{~m}$ with the Holocene section accounting for $20 \mathrm{~cm}$ (again a marly ooze). The remainder of the section contains clay and mud with varying amounts of silt and fine sand. The upper Pleistocene section is interpreted as fine-grained turbidites and hemipelagic sediments. At Site 621, a thin Holocene section overlays a thick section of monotonous mud with increasing silt and sand content downhole (total depth $214.8 \mathrm{~m}$ ). Similar to the other midfan sites, $\sim 25 \mathrm{~cm}$ of Holocene section was recovered at Site 622 (total depth $208.0 \mathrm{~m}$ ) and the remaining section is very similar to that recovered at Site 621 .

Bulk- and molecular-level parameters at the middle fan sites are very similar to those observed at the lower fan sites. Interstitial sulfate concentrations are nondetectable at relatively shallow depths at both channel Sites 621 and 622 (Fig. 2). Sulfate concentrations at overbank Sites 617 and 620 often exceed that of seawater (range 29.0 to $38.1 \mathrm{mM}$ ). $\Sigma \mathrm{CO}_{2}$ concentrations range from 29.9 to $255.9 \mathrm{mg} \mathrm{C} / \mathrm{L}$ and are highest in the low sulfate regions (Fig. 3).

Total organic carbon (TOC) content ranges from 0.5 to $2.1 \%$, averaged $0.9 \pm 0.2 \%(n=70)$, and is uniformly distributed (Fig. 10). Carbon to nitrogen elemental ratios $(\mathrm{C} / \mathrm{N})$ and carbon-isotope compositions $\left(\delta^{13} \mathrm{C}\right)$ are indicative of terrestrially derived organic matter, as was also true at the lower fan sites (Fig. 10).

Also, as at lower fan sites, individual alkane concentrations are in the 0 to $1000 \mathrm{ppb}$ range, increase with depth, and appear to be due to nonindigenous thermogenic hydrocarbons (Figs. 11 and 12). Hydrocarbon concentrations increase by almost a factor of 10 over the length of the core. Molecular-level compositions indicate a mixture of thermogenic and biologically produced terrestrial hydrocarbons (Fig. 5B-D); little planktonic input is apparent. The UCM concentration increases with depth while the CPI decreases with depth as at the lower fan sites (Figs. 11 and 12). In general, the fluorescence spectra of extracts from channel Sites 621 and 622 are dominated by the fluorescence of perylenes.

\section{Fan Margin Site (616)}

Site 616 was chosen in order to drill on the fan margin (Fig. 1). Initial results conclude that a different fan lobe was penetrated at Site 616 than at all other sites. Total penetration was $371.0 \mathrm{~m}$. The Holocene section is less than $1 \mathrm{~m}$ thick. The rest of the section consists of fine grained mud and sand (see Site 616 chapter, this volume).

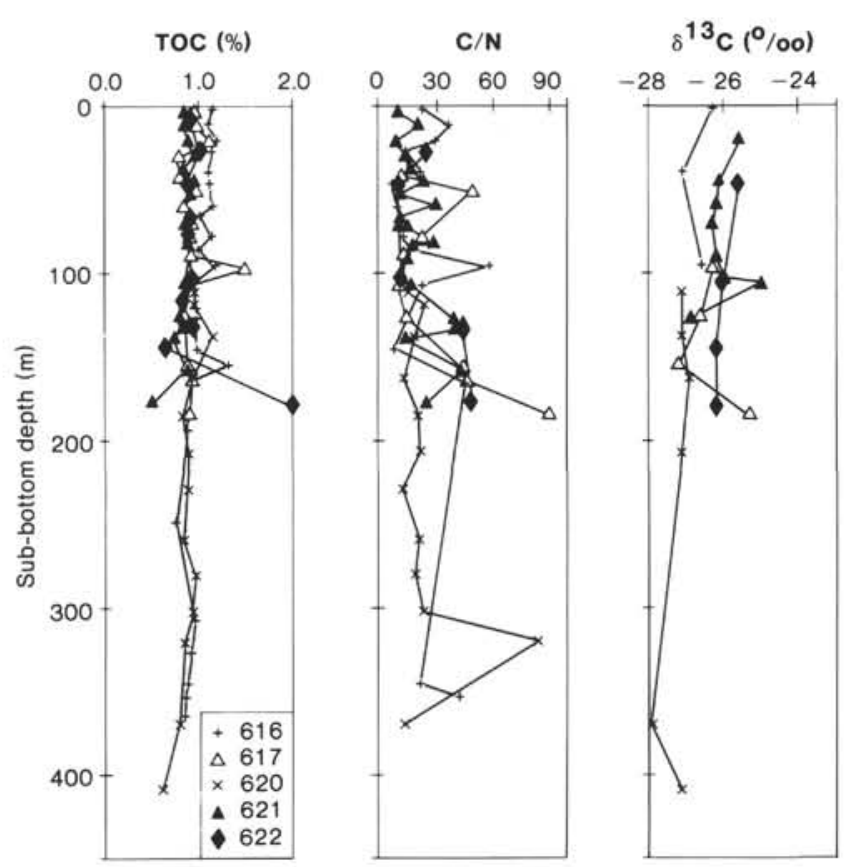

Figure 10. Vertical distribution of total organic carbon content (TOC), organic carbon to nitrogen elemental ratios $(\mathrm{C} / \mathrm{N})$, and $\delta^{13} \mathrm{C}$ of organic matter at middle fan and fan margin sites.
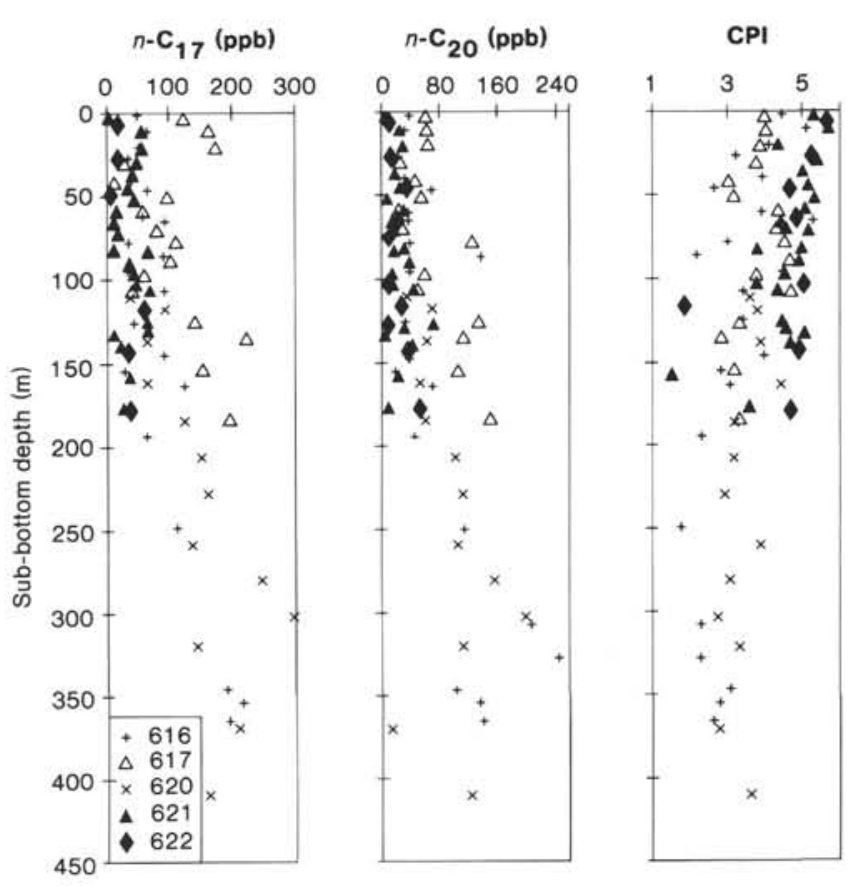

Figure 11. Vertical distribution of $n-\mathrm{C}_{17}, n-\mathrm{C}_{20}$, and carbon preference index (CPI) at middle fan and fan margin sites.

The organic geochemical results for the single site on the fan margin are very similar to those observed at lower and middle fan sites; data are summarized in Figures 2, 3 , and 10-12. Organic carbon content ranges from 0.8 to 1.3 , averages $1.0 \pm 0.1 \%(n=23)$, and decreases slightly with depth (Fig. 10). Bulk- and molecular-level parameters suggest a mixed petrogenic and terrestrial biogenic source for the organic matter. Vertical trends again 


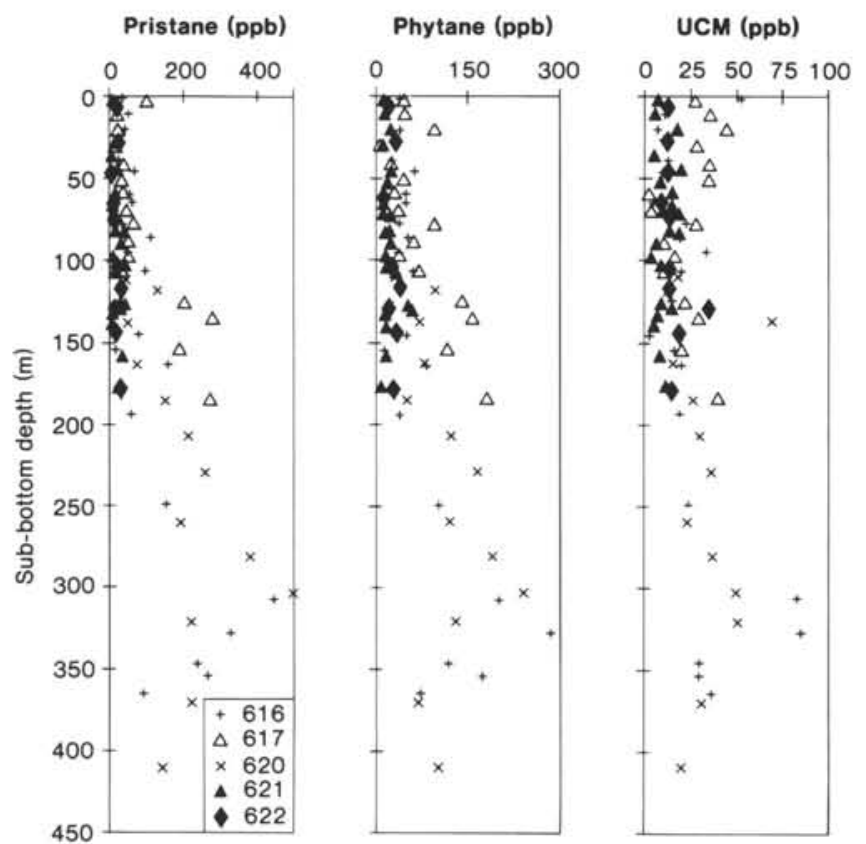

Figure 12. Vertical distribution of pristane, phytane, and the unresolved complex mixture (UCM) at middle fan and fan margin sites.

suggest upward migration of thermogenic hydrocarbons from a deeper source (Figs. 11 and 12).

\section{Intraslope Basins Sites $(618,619)$}

Site 618 is located near the center of the northern sub-basin of Orca Basin (Fig. 1). Orca Basin is an interdomal basin formed when a group of diapirs coalesced, surrounding a depression. Orca Basin is unique in that it contains $\sim 200 \mathrm{~m}$ of hypersaline anoxic bottom water. Total drilling depth at Site 618 was $92.5 \mathrm{~m}$. A local Holocene slide produced a uniform gray clay layer from 0 to $16 \mathrm{~m}$ sub-bottom. Underneath this section there is a 1.5$\mathrm{m}$ layer of dark black anoxic sediment. Further downhole, the sediments are again gray but occasionally are interbedded with thin black clay. The deepest black layer is at $41 \mathrm{~m}$; below this depth the core was predominantly gray (see Site 618 chapter, this volume). Site 619 in the Pigmy Basin provided samples from a blocked-canyon intraslope basin (Fig. 1). This type of basin is formed by either the blockage of a submarine canyon or upper fan valley by diapirism or bottom transport of sediments. This basin, in contrast to Orca Basin, is overlain by oxic oceanic seawater. Site 619 penetration was $208.7 \mathrm{~m}$. Hemipelagic muds containing only minor amounts of thin sandy-silt turbidites were recovered. Ericson's Zones Z, Y, and X (Ericson and Wollin, 1968; Kohl, this volume) were well preserved; more than $4.5 \mathrm{~m}$ of Holocene section were recovered (see Site 619 chapter, this volume).

Total organic carbon concentrations are relatively uniform in sediments from Site 618 (range 0.6 to 1.0; averaged $0.6 \pm 0.1 \%, n=16$; Fig. 13). Carbon to nitrogen elemental ratios are slightly lower than at the fan sites, but are still indicative of a predominance of terrestrially sourced organic matter. This interpretation is supported by the $\delta^{13} \mathrm{C}$ of the organic matter which ranges from -25.5 to $-26.8 \%$. Displaced Pleistocene material
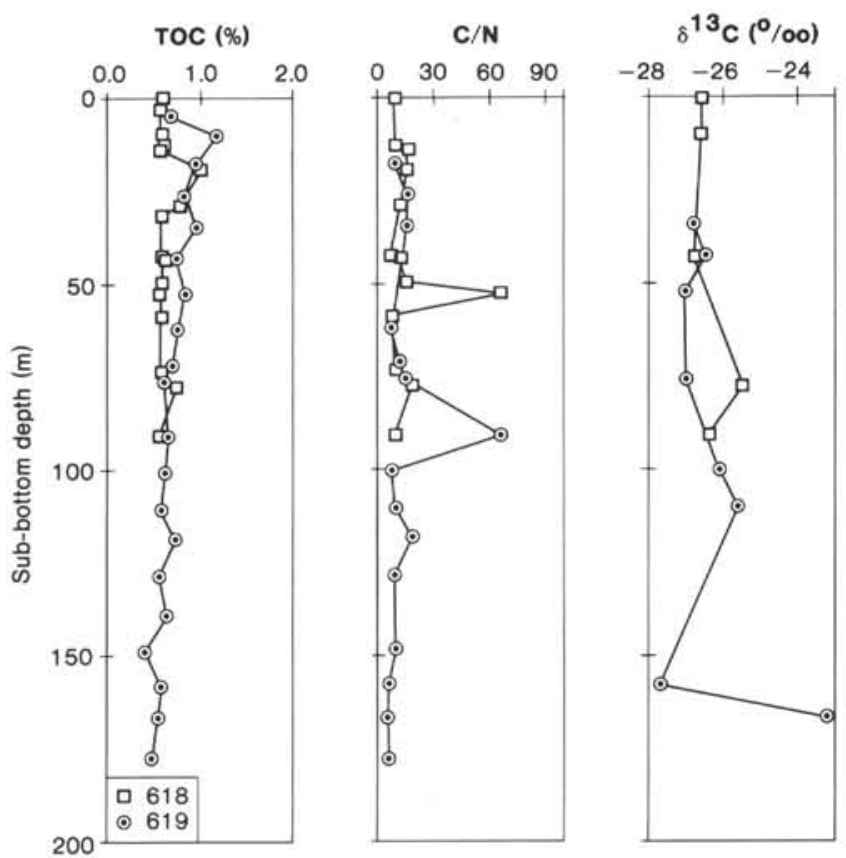

Figure 13. Vertical distribution of total organic carbon content (TOC), organic carbon to nitrogen elemental ratios $(\mathrm{C} / \mathrm{N})$, and $\delta^{13} \mathrm{C}$ of organic matter at intraslope basin sites.

overlies Holocene sediments at this site (see Site 618 chapter, this volume) and accounts for the $-26.6 \% 0 \delta^{13} \mathrm{C}$ observed in the Ericson $\mathrm{Z}$ zone (Ericson and Wollin, 1968). Sediments are gassy throughout the length of the sediment column, with sulfate levels below detection limits in all pore waters except the sample from a depth of $2.95 \mathrm{~m}$ sub-bottom (see Fig. 2 and Pflaum et al., this volume).

Extractable organic matter concentrations are relatively high and variable, ranging from 99.1 to $393 \mathrm{ppm}$ with no apparent vertical trends. Gas chromatographic analyses demonstrate a hydrocarbon distribution similar to that at the fan sites (Fig. 14; compare with Fig. 5). A mixture of biogenic and thermogenic hydrocarbons is present. Orca Basin sediments' alkane concentrations do not increase regularly with depth (Figs. 15 and 16). Vertical trends are not apparent in the UCM concentrations or the CPI (Fig. 16).

Pigmy Basin (Site 619) total organic carbon contents decrease by a factor of two over the interval sampled (range 0.4 to 1.2 ; average $0.7 \pm 0.2 \%, n=21$; Fig. 13). Carbon to nitrogen elemental ratios range from 5.6 to 68 , with a number of measurements approaching average planktonic values (Fig. 13). $\delta^{13} \mathrm{C}$ values for the bulk organic matter are relatively negative indicating a predominantly terrestrial organic matter origin in contrast to the $\mathrm{C} / \mathrm{N}$ ratios (Fig. 13). Sulfate concentrations decrease regularly from $24.1 \mathrm{mM}$ to 0 at $70 \mathrm{~m}$ sub-bottom depth (Fig. 2).

As at all previously sampled sites, molecular-level hydrocarbon compositions at the Pigmy Basin site reflect a mixed biologic and thermogenic source (Fig. 14). Individual alkane distributions exhibit a subsurface maxima that coincides with the zero sulfate level (Figs. 15 and 16). The UCM concentrations are more erratically dis- 

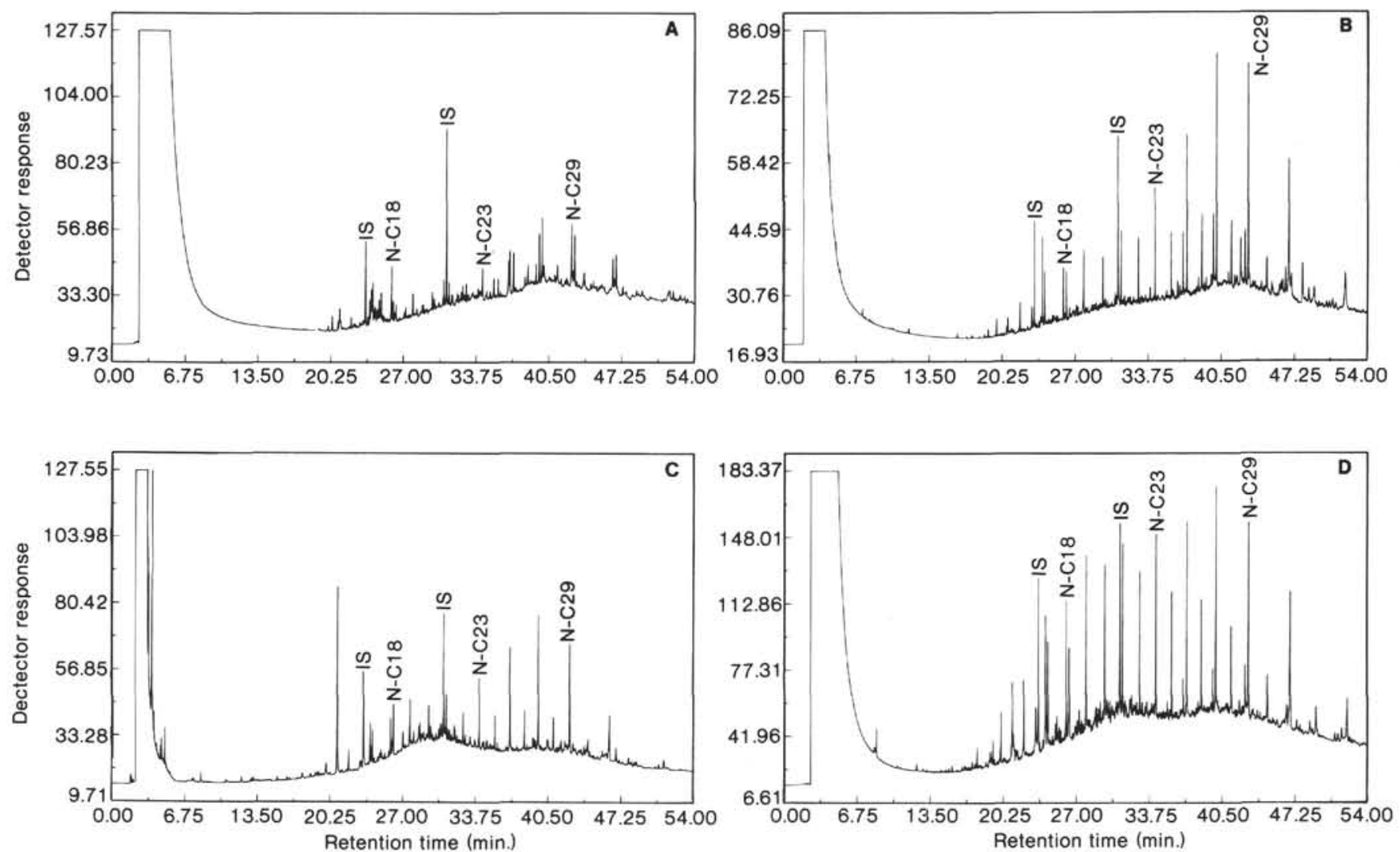

Figure 14. Gas chromatograms of selected sediment extracts from intraslope basin sites (for GC conditions see Figure 5). (A) Site 618, Orca Basin, $0.01 \mathrm{~m}$ sub-bottom; (B) Site 618, Orca Basin, $77.32 \mathrm{~m}$ sub-bottom; (C) Site 619, Pigmy Basin, $9.94 \mathrm{~m}$ sub-bottom; (D) Site 619, Pigmy Basin, $118.23 \mathrm{~m}$ sub-bottom.

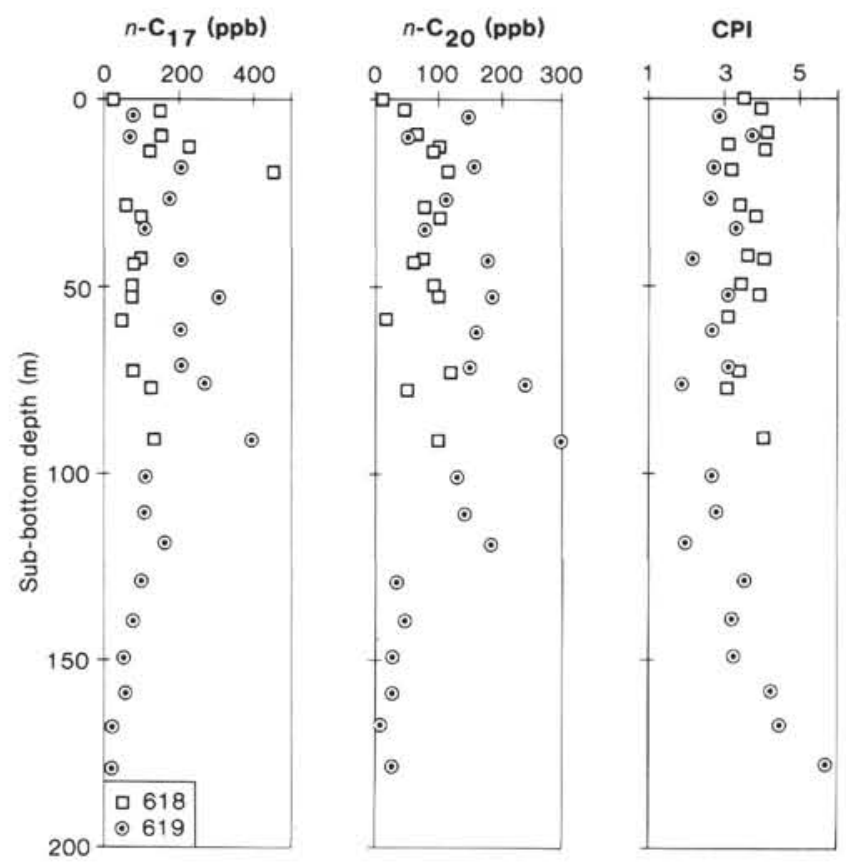

Figure 15. Vertical distribution of $n-\mathrm{C}_{17}, n-\mathrm{C}_{20}$, and carbon preference index (CPI) at intraslope basin sites.
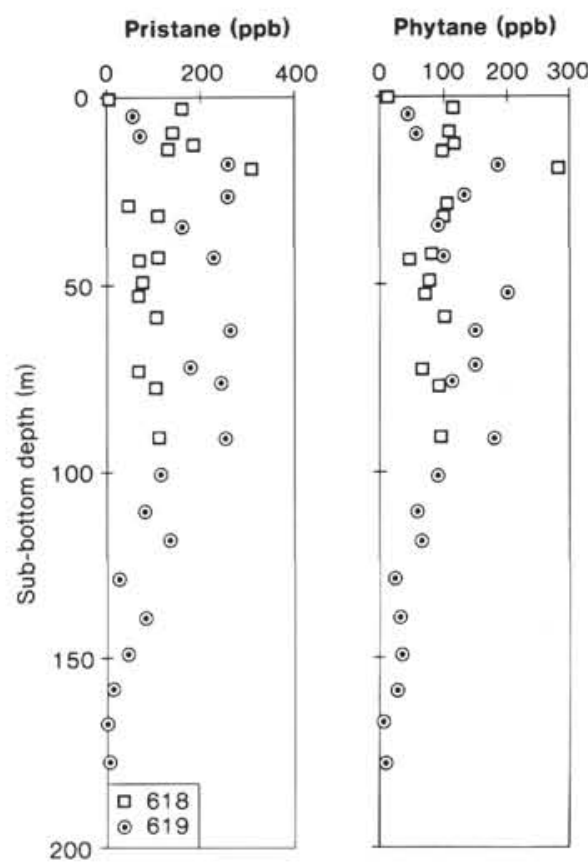

UCM (ppb)

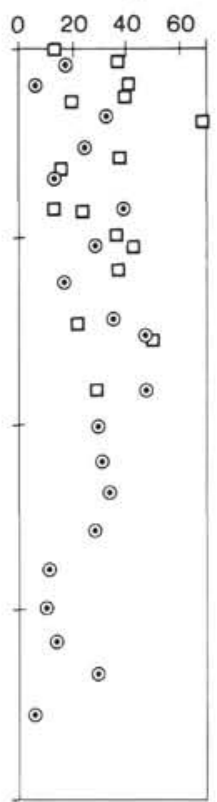

Figure 16. Vertical distribution of pristane, phytane, and the unresolved complex mixture (UCM) at intraslope basin sites. 
tributed but show a similar trend (Fig. 16). The CPI profile exhibits a minimum at the same depth as the alkane maximum (Fig. 16). Fluorescence analyses confirm the presence of both thermogenic aromatic compounds and perylenes (Fig. 17).

\section{DISCUSSION AND SUMMARY}

\section{Fan Sites (614-617, 620-623)}

At all Mississippi Fan locations, the bulk organic matter in fine-grained sediments was chemically and isotopically similar to terrestrially sourced organic matter. Large amounts of lignitic or woody material occur sporadically throughout the cores and are preferentially associated with sand-dominated sections. Carbon-isotope composition, carbon to nitrogen elemental ratios, the presence of significant amounts of plant biowaxes, and lithologic associations confirm this interpretation. This dominance of terrestrial material results from sediment outflow from the Mississippi River system. Sediment contributed by erosion of the Mississippi Canyon to form the fan lobes rapidly dilutes any planktonic input. Planktonic debris is also more labile than terrestrial organic matter and is therefore more rapidly remineralized in the
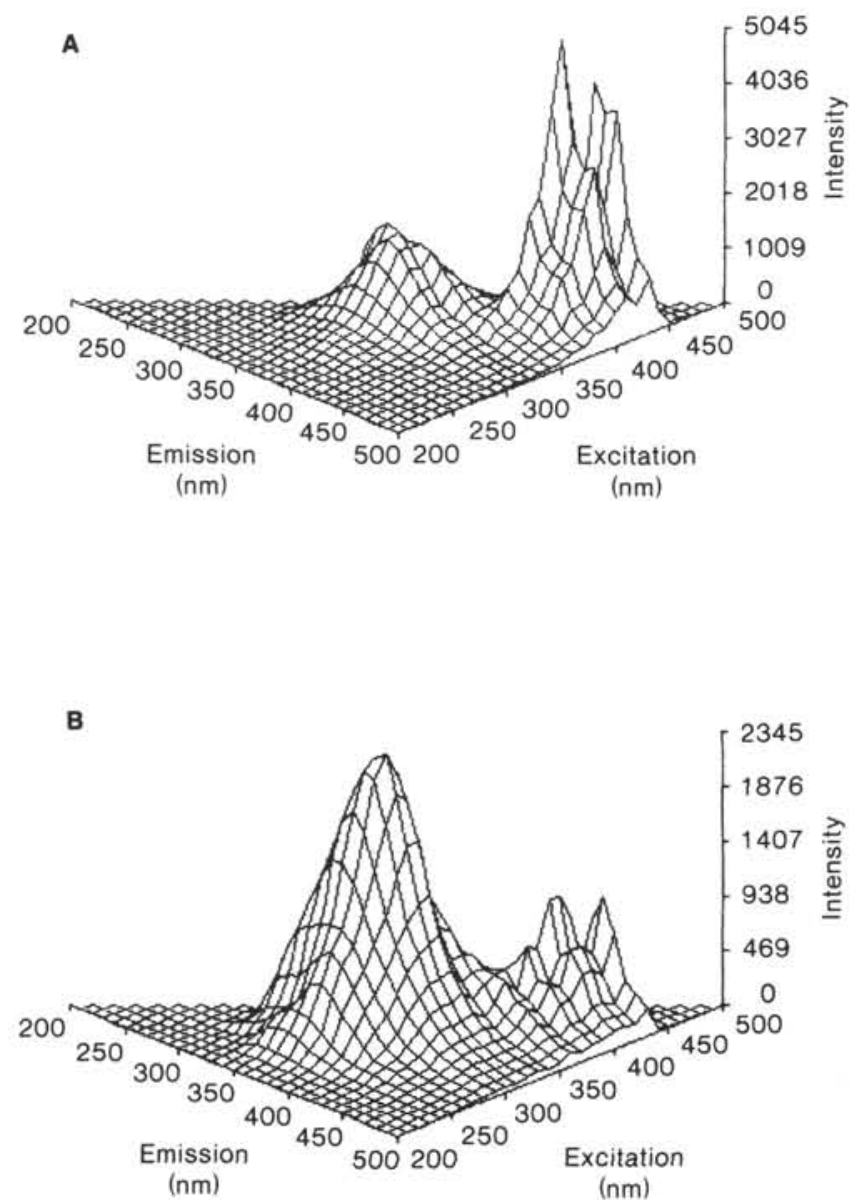

Figure 17. Total scanning fluorescence spectra of selected sediment extracts from the intraslope basin sites. (A) Site $618,42.75 \mathrm{~m}$ subbottom; (B) Site 619, $118.23 \mathrm{~m}$ sub-bottom. water column and in surficial sediments (Meyers et al., 1984 and references cited therein).

Molecular-level (gas chromatography, HPLC/DAS, GC/MS, and fluorescence) analyses confirm the presence of thermogenic hydrocarbons at all fan sites. Vertical profiles of individual alkanes, UCM, and CPI suggest that thermogenic, high molecular weight hydrocarbons are migrating upward from a deeper source. Neither sufficient temperature nor time has been available for these hydrocarbons to be produced in situ. The extractable organic matter includes both thermogenic hydrocarbons and recent biologically produced hydrocarbons, with the former dominating as an unresolved complex mixture.

\section{Intraslope Basin Sites (618 and 619)}

Similar to fan sites, bulk organic matter parameters suggest a predominantly terrestrial origin for the Pleistocene organic matter in the intraslope basin sediments. Carbon to nitrogen elemental ratios are shifted toward the planktonic end member, but carbon-isotope compositions remain relatively negative. Nondetectable sulfate levels were encountered at both sites, although this level occurs at a significantly deeper sub-bottom depth at the Pigmy Basin site.

Also similar to fan sites, significant amounts of nonindigenous migrated hydrocarbons were detected in sediments from both intraslope basins. Because of the low temperatures present at the depths sampled, a deeper hydrocarbon source is inferred. Vertical hydrocarbon distributions are particularly erratic in the Orca Basin (Site 618 ) profile. Pigmy Basin (Site 619) hydrocarbon profiles were more disturbed than was observed at the fan sites. The observed erratic hydrocarbon distributions can be explained by extensive sediment reworking (slumping, bioturbation), consumption of hydrocarbons (microbial), horizontal movement of hydrocarbons, and/or the saturation of adsorptive sites. A subsurface maximum in individual hydrocarbon concentrations that coincides with the zero sulfate level was observed at the Pigmy Basin site; the explanation for this co-occurrence is not clear at present.

\section{ACKNOWLEDGMENTS}

Research support for this study was provided by the National Science Foundation through Grant OCE-83-01538. The Center for Energy and Mineral Resources at Texas A\&M University provided instrumentation support. An earlier version of this manuscript benefited from the reviews of $\mathrm{C}$. Barker and an anonymous reviewer.

\section{REFERENCES}

Anderson, R. K., Scalan, R. S., Parker, P. L., and Behrens, E. W., 1983. Seep oil and gas in Gulf of Mexico slope sediments. Science, 222:619-621.

Barker, C., 1979. Organic geochemistry in petroleum exploration. Am. Assoc. Pet. Geol. Continuing Education Course Note Series, 10.

Brooks, J. M., Kennicutt, M. C., II, Barnard, L. A., Denoux, G. J., and Carey, B. D., 1983. Application of total scanning fluorescence to exploration geochemistry. Proc. Annu. Offshore Technol. Conf., 15th Houston, Texas, pp. 393-400.

Brooks, J. M., Kennicutt, M. C., II, Fay, R. A., McDonald, T. J., and Sassen, R., 1984. Thermogenic gas hydrates in the Gulf of Mexico. Science, 225:409-411. 
Eckleman, W. R., Broecker, W. S., Whitlock, D. W., and Allsup, J. R., 1962. Implications of carbon isotopic composition of total organic carbon of some recent sediments and ancient oils. Am. Assoc. Petrol. Geol. Bull., 46:699-704.

Eglinton, G., and Hamilton, R. J., 1963. The distribution of alkanes. In Swain, T. (Ed.), Chemical Plant Taxonomy: New York (Academic Press), pp. 187-218.

1967. Leaf epicuticular waxes. Science, 156:1322-1334

Ericson, D. B., and Wollin, G., 1968. Pleistocene climates and chronology in deep-sea sediments. Science, 162:1227-1234.

Farrington, J. W., Teal, J. M., Quinn, J. G., Wade, T., and Burns, K. 1973. Intercalibration of analyses of recently biosynthesized hydrocarbons and petroleum hydrocarbons in marine lipids. Bull. Environ. Cont. Toxicol., 10:129-136.

Farrington, J. W., and Tripp, B. W., 1977. Hydrocarbons in Western North Atlantic sediments. Geochim. Cosmochim. Acta, 41:16271641.

Gardner, W. S., and Menzel, D. W. 1974. Phenolic aldehydes as indicators of terrestrially derived organic matter in the sea. Geochim. Cosmochim. Acta, 38:813-822.

Gearing, J. N., Gearing, P. J., Rudnick, D. T., Requejo, A. G., and Hutchins, M. J., 1984. Isotopic variability of organic carbon in a phytoplankton-based, temperate estuary. Geochim. Cosmochim. Acta, 48:1089-1098.

Gearing, P., Gearing, J. N., Lytle, T. F., and Lytle, J. S., 1976. Hydrocarbons in 60 northeast Gulf of Mexico sediments. A preliminary survey. Geochim. Cosmochim. Acta, 40:1005-1017.

Gearing, P. Plucker, F. E., and Parker, P. L., 1977. Organic carbon stable isotope ratios of continental margin sediments. Mar. Chem., $5: 251-266$.

Giger, W., and Schaffner, C., 1977. Aliphatic, olefinic, and aromatic hydrocarbons in recent sediments of a highly eutrophic lake. In Campos, R. and Goni, J. (Eds.), Advances in Organic Geochemistry: Madrid (Endisma), pp. 375-390.

Giger, W., Schaffner, C., and Wakeham, S. G., 1980. Aliphatic and olefinic hydrocarbons in recent sediments of Greifensee, Switzerland. Geochim. Cosmochim. Acta, 44:119-129.

Hedges, J. I., and Parker, P. L., 1976. Land derived organic matter in surface sediments from the Gulf of Mexico. Geochim. Cosmochim. Acta, 40:1019-1029.

Kennicutt, M. C., II, and Brooks, J. M., 1983. Relationship between pelagic tar, fluorescence, and biological markers in the South Atlantic Ocean. Mar. Poll. Bull., 14:335-342.

Kennicutt, M. C., II, Brooks, J. M., McDonald, T. J., and Pflaum, R. C., 1985. Nonvolatile organic matter at Sites 565-570, DSDP Leg 84. In von Huene, R., Aubouin, J., et al., Init. Repts. DSDP, 84: Washington (U.S. Govt. Printing Office), 705-718.
Kennicutt, M. C., II, and Jeffrey, L. M., 1981a. Chemical and gc-ms characterization of marine dissolved lipids. Mar. Chem., 10:367387.

1981b. Chemical and gc-ms characterization of marine particulate lipids. Mar. Chem., 10:389-407.

Kollatukudy, P. E., and Walton, T. J., 1973. The biochemistry of plant cuticular lipids. In Holman, R. D. (Ed.), Progress in Chemistry of Fats and Other Lipids, Part 3, (Vol. XIII): New York (Pergammon Press), 121-275.

Meyers, P. A., Leenher, M. J., Eadie, B. J., and Maule, S. J., 1984. Organic geochemistry of suspended and settling particulate matter in Lake Michigan. Geochim. Cosmochim. Acta, 48:443-452.

Müller, P. J., 1977. C/N ratios in Pacific deep sea sediments: effect of inorganic ammonium and organic nitrogen compounds sorbed by clays. Geochim. Cosmochim. Acta, 41:765-776.

Newman, J. W., Parker, P. L., and Behrens, E. W., 1973. Organic carbon isotope ratios in Quaternary cores from the Gulf of Mexico. Geochim. Cosmochim. Acta, 37:225-238.

Prahl, F. G., Bennett, T. J., and Carpenter, R., 1980. The early diagenesis of aliphatic hydrocarbons and organic matter in sedimentary particulates from Dabob Bay, Washington. Geochim. Cosmochim. Acta, 44:1967-1976.

Prahl, F. G., and Carpenter, R., 1979. The role of zooplankton fecal pellets in the sedimentation of polycyclic aromatic hydrocarbons in Dabob Bay, Washington. Geochim. Cosmochim. Acta, 43:19591972.

Sackett, W. M., 1964. The depositional history and isotopic organic carbon composition of marine sediments. Mar. Geol., 2:173-185.

Sackett, W. M., Nakaparkin, S., and Dalymple, D., 1970. Carbon isotope effects in methane production by thermal cracking. In Hobson, G. D., and Speers, G. C. (Eds.), Advances in Organic Geochemistry 1966: New York (Pergammon), pp. 37-53.

Sackett, W. M., and Thompson, R. R., 1963. Isotopic organic carbon composition of recent continental derived clastic sediments of eastern Gulf coast, Gulf of Mexico. Bull. Am. Assoc. Pet. Geol., 47: 525-531.

Tullock, A. P., 1976. Chemistry of waxes of higher plants. In Kolattukudy, P. E. (Ed.), Chemistry and Biochemistry of Natural Waxes: New York (Elsevier), pp. 236-287.

Wakeham, S. G., and Carpenter, R., 1976. Aliphatic hydrocarbons in sediments of Lake Washington. Limnol. Oceanogr., 21:711-723.

Date of Initial Receipt: 6 February 1985

Date of Acceptance: 17 April 1985 